diagnosis of the orocraniodigital syndrome, our patient has a more widespread skeletal dysplasia, with absence of thumbs, and isolated growth hormone deficiency. As he is the only child of nonconsanguineous parents, no further information is gained regarding the mode of inheritance.

\section{References}

1 Juberg R C, Hayward J R. A new familial syndrome of oral, cranial, and digital anomalies. J Pediatr 1969; 74: 755-62.

2 Nevin N C, Henry P, Thomas P T S. A case of the orocraniodigital (Juberg-Hayward) syndrome. $\mathrm{J}$ Med Genet $1981 ; 18$ : 478-80.
${ }^{3}$ Savage D C L, Swift P G F, Johnston P G B, Goldie D J, Murphy D. Combined test of anterior pituitary function in children. Arch Dis Child 1978; 53: 301-4.

4 Juberg R C. Oro-cranio-digital syndrome. In: Bergsma D, ed. Birth defects compendium, second edition. New York: Liss, 1979: 828.

5 Rudman D, Davis G T, Priest J H, et al. Prevalence of growth hormone deficiency in children with cleft lip or palate. J Pediatr 1978; 93: 378-2.

6 Kato K. Congenital absence of the radius. $J$ Bone Joint Surg 1924; 6: 589-626.

Correspondence to Dr H M Kingston, Section of Medical Genetics, Department of Medicine, Welsh National School of Medicine, Heath Park, Cardiff CF4 4XN.

Received 27 May 1982

\title{
Neonatal rickets in one of identical twins
}

\section{Z KOVAR, P MAYNE, AND J WALLIS \\ Department of Child Health and Department of Chemical Pathology, Westminster Medical School and Hospital, London}

SUMMARY We report a case of rickets in one of identical low birthweight twin infants. Plasma 25-hydroxycholecalciferol concentrations were normal in both infants; there was good clinical response to $1-\alpha$ hydroxycholecalciferol. We suggest that there was a delay in maturation of renal 25 -hydroxycholecalciferol-1 $\alpha$ hydroxylase enzyme.

The problem of rickets in the low birthweight infant has been known for some time. ${ }^{1}$ The diagnosis is made on clinical, biochemical, and radiological criteria; serial measurement of plasma alkaline phosphatase activity is useful to screen for disease. ${ }^{2}$ The aetiology of neonatal rickets is multi-factorial. We report a case of rickets in one of identical twins.

\section{Case report}

Female twins (I vertex, II breech) were born at 30 weeks' gestation after a normal pregnancy to a 23-year-old healthy well-nourished white primigravida. The membranes of twin I ruptured spontaneously 36 hours before, and those of twin II at delivery. The placenta weighed $680 \mathrm{~g}$ and was monochorionic and diamniotic. The blood group of both infants was $\mathrm{ORh}^{+}\left(\right.$mother $\left.\mathrm{ARh}^{+}\right)$and identical antigens for the common groups, including Lutheran, Lewis, and Duffy were found. The genotype was $\mathbf{M}+\mathbf{N}+\mathbf{S}-\overline{\mathbf{s}}+\mathbf{P}+\mathbf{L u}^{\mathrm{a}-\mathrm{Le}}(\mathbf{a}-\mathbf{b}+)$ $\mathrm{Fy}^{(a+b+)}$ for both children.

Plasma alkaline phosphatase, calcium, and inorganic phosphorus were measured serially from age 2 weeks. ${ }^{2}$ Rickets was diagnosed in twin II at age 6 weeks (36 weeks' post-conceptional age). There was no evidence of rickets in twin I either at this age
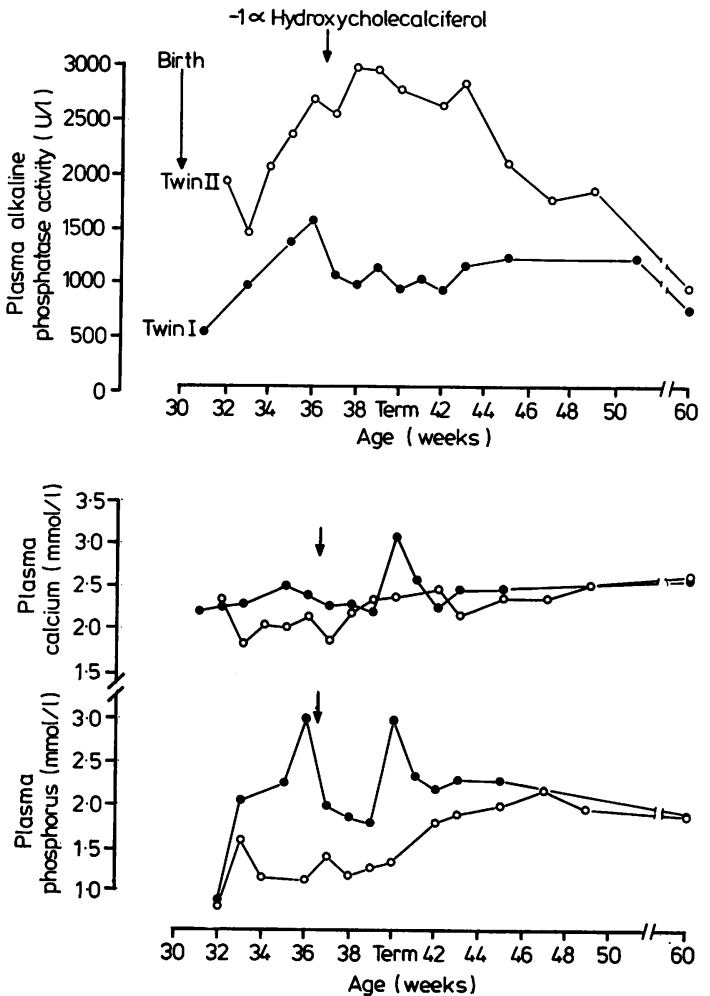

Childhood reference ranges ${ }^{2}$ : Plasma alkaline phosphatase upper limit $850 \mathrm{U} / 1$, plasma calcium $2.20-2.67 \mathrm{mmol} / 1$, plasma inorganic phosphorus $1.02-1.96 \mathrm{mmol} / \mathrm{l}$.

Conversion: SI to traditional units - plasma calcium: $1 \mathrm{mmol} / 1 \approx$ $4.0 \mathrm{mg} / 100 \mathrm{ml}$. Plasma inorganic phosphorus: $1 \mathrm{mmol} / 1 \approx 3.0 \mathrm{mg} /$ $100 \mathrm{ml}$.

Figure Serial plasma alkaline phosphatase, calcium, and inorganic phosphorus in both twins. 
Table Clinical information on twins $I$ and II; same day results at time of diagnosis in twin II

\begin{tabular}{|c|c|c|}
\hline & Twin I & Twin II \\
\hline $\begin{array}{l}\text { Weight (kg) } \\
\text { Apgar score (at one and five min) } \\
\text { Clinical problems }\end{array}$ & $\begin{array}{l}1.2 \\
5,9 \\
\text { (1) Hyaline membrane disease } \\
\text { positive pressure } \\
\text { ventilation } \\
\text { (2) Hyperbilirubinaemia } \\
\text { normal liver transaminases } \\
\text { treatment: exchange transfusion } \\
\text { (x 2), phototherapy } \\
\text { (3) Anaemia (lowest } \mathrm{Hb} 7 \cdot 8 \mathrm{~g} / \mathrm{dl}) \\
\text { mild haemolysis (physiological) } \\
\text { (4) Neonatal apnoea }\end{array}$ & $\begin{array}{l}1.0 \\
8,8 \\
\text { (1) Cyanotic episodes (x 2) } \\
\text { infection } \\
\text { (2) Hyperbilirubinaemia } \\
\text { normal liver transaminases } \\
\text { treatment: phototherapy } \\
\text { (3) Anaemia (lowest Hb } 6.6 \mathrm{~g} / \mathrm{dl}) \\
\text { moderate haemolysis } \\
\text { increased Hb response to vitamin E } \\
\text { therapy } \\
\text { (4) Rickets }\end{array}$ \\
\hline $\begin{array}{l}\text { Results } \\
X \text {-ray film } \\
\text { Plasma alkaline phosphatase (U/I) } \\
\text { Plasma alkaline phosphatase isoenzyme pattern } \\
\text { 25-OHCC } \mu \text { g/I (ARR 25-43) } \\
\text { Parathyroid hormone ng/l (ARR 275-1200) } \\
\text { Copper } \mu \mathrm{mol} / 1 \text { (RR 11-25) } \\
\text { Vitamin E } \mu \mathrm{mol} / 1 \text { (RR 11·5-35) } \\
\text { Generalised aminoaciduria } \\
\text { Viral/bacterial studies } \\
\text { Treatment }\end{array}$ & $\begin{array}{l}\text { No rickets } \\
1500 \\
\text { Bone } \\
53 \\
260 \\
-\overrightarrow{11 \cdot 6} \\
+ \\
\text { Negative } \\
\text { Antibiotics }\end{array}$ & $\begin{array}{l}\text { Rickets } \\
2500 \\
\text { Bone } \\
38 \\
940 \\
12 \cdot 9 \\
4 \cdot 1 \text { (after treatment } 17 \cdot 5) \\
+++ \\
\text { Negative } \\
\text { Antibiotics, oral fat soluble vitamin E, } \\
\quad 1-\alpha \text {-hydroxycholecalciferol }\end{array}$ \\
\hline
\end{tabular}

$25 \mathrm{OHCC}=25$-hydroxycholecalciferol. ARR $=$ adult reference range (A Fairney, 1980, personal communication). $R \mathbf{R}=$ reference range.

or subsequently. Twin II had craniotabes and slowed linear growth; twin I continued to grow parallel to her centile. The clinical details and investigations done at the time of diagnosis in twin II are listed in the Table; serial biochemical data are shown in the Figure.

Both infants had similar intakes of calciferol, calcium, and phosphorus; oral feeding was established by the end of the first week of life and was initially mother's expressed breast milk and later commercial formula*. The volume of feeding in both infants was between 150 and $200 \mathrm{ml} / \mathrm{kg}$ a day after the first week.

Twin II was treated with 0.08 increasing to 0.20 $\mu \mathrm{g} / \mathrm{kg} 1 \alpha$ hydroxycholecalciferol $\dagger$, and no additional calcium or phosphorus was given. Longitudinal growth increased with evidence of healing on the $x$-ray films by age 20 weeks; treatment was stopped at 38 weeks.

\section{Discussion}

The aetiology of rickets in the neonatal period ${ }^{3}$ is often unknown, but has been attributed to prenatal or postnatal calciferol deficiency, calcium or phosphorus deficiency, a disturbance in the metabolic pathway of cholecalciferol, or defective mineralisation despite adequate substrate.

* Cow and Gate Premium, Cow and Gate, Wiltshire.

$\dagger$ Leo Laboratories Ltd. Buckinghamshire.
Although both infants came from the same antenatal nutritional environment, twin II was lighter than twin I, but with no obvious intrauterine growth retardation. The placenta was single and the blood group genotypes identical. The chance of being nonidentical with these criteria alone is less than $0.03 .^{4}$

There was no clinical or biochemical evidence of malabsorbtion, nor was there hepatic or renal disease which might affect cholecalciferol metabolism; the generalised aminoaciduria that was seen is common in preterm infants. The exchange transfusions performed on days 4 and 7 may have prevented rickets in twin $I$ by providing additional calciferol or inorganic phosphorus; we can only speculate on this possibility. The initial plasma inorganic phosphorus concentrations were however comparable in both infants on day 14 which would argue against this. Serum copper concentration in twin II was normal making copper deficiency unlikely as a cause for the bony changes seen. ${ }^{5}$

Both these infants had similar intakes of calcium, phosphorus, and calciferol before the development of rickets in twin II; a deficiency is therefore not the likely aetiology. The parathyroid hormone concentration in twin II was compatible with secondary hyperparathyroidism seen in infants (A Fairney, 1980, personal communication); we suggest that the low plasma inorganic phosphorus concentration in the affected twin was due to the phosphaturic effect of secondary hyperparathyroidism. The plasma alkaline phosphatase activity in twin I, although 
increased above childhood reference ranges, is commonly present in the preterm infant ${ }^{2}$ and we do not believe that it alone represents subclinical rickets. The 25-hydroxycholecalciferol concentrations were within a normal range for both infants; ${ }^{6}$ assays for 1,25 and 24,25-dihydroxycholecalciferol were not available. End-organ unresponsiveness to the active 1,25 dihydroxycholecalciferol is an unlikely cause in this case because of the rapid clinical response to $1 \alpha$ hydroxycholecalciferol (Leo). In favour of a transient 25-hydroxycholecalciferol-1 $\alpha$ hydroxylase enzyme deficiency in twin II is the presence of adequate initial plasma concentrations of 25-hydroxycholecalciferol, the absence of obvious renal disease, and the favourable response to $1 \alpha$ hydroxycholecalciferol, so that this treatment could subsequently be stopped. Although both infants should have had identical enzyme complements there may have been a difference in the timing of enzyme maturation. The only major difference between the two infants was the severity of the early clinical course in twin I and the development of rickets in twin II. This is contrary to what one might expect.

We suggest that in this infant the cause was a maturational delay in hydroxylation of 25-hydroxycholecalciferol. We do not know of any previous report of neonatal rickets in one of identical twins.
We thank Dr D Barltrop for advice, Ms Julie Patton for performing the genotype studies, and Dr Angela Fairney for the 25-hydroxycholecalciferol and parathyroid hormone assays.

\section{References}

1 Von Sydow G V A. Study of the development of rickets in premature infants. Acta Paediatr Scand [Suppl] 1946; 33: Supplement 2, 1-122.

2 Kovar I, Mayne P, Barltrop D. Plasma alkaline phosphatase activity: a screening test for rickets in preterm neonates. Lancet 1982; i: 308-10.

${ }^{3}$ Chesney R W, Hamstra A J, De Luca H F. Rickets of prematurity: supra-normal levels of 1, 25-dihydroxyvitamin D. Am J Dis Child 1981; 135: 34-7.

4 Barnett A H, Eff C, Leslie R D G, Pyke D A. Diabetes in identical twins. Diabetologia 1981; 20: 87-93.

5 Griscom N T, Craig J N, Neuhauser E B D. Systemic bone disease developing in small preterm infants. Pediatrics $1971 ; 48$ : 883-5.

6 Hoff N, Haddad J, Teitelbaum S, McAlister W, Hillman L S. Serum concentrations of 25-hydroxyvitamin D in rickets of extremely premature infants. J Pediatr 1979; 94: 460-6.

Correspondence to Dr Ilya Kovar, Department of Child Health, Westminster Children's Hospital, Vincent Square, London SW1P 2NS.

Received 8 July 1982 